\title{
Gender studies in the Tempos e Espaços em Educação Journal:
}

\section{a systematic review}

SILVA, Ivanderson Pereira da (Maceió, Alagoas, Brasil) $)^{1 *}$

DIAS, Alfrancio Ferreira (Aracaju, Sergipe, Brasil) ${ }^{2^{* *}}$

RIOS, Pedro Paulo Souza (Salvador, Bahia, Brasil) $)^{3+* *}$

${ }^{1}$ Universidade Federal de Alagoas, Departamento de Educação, Curso de Graduação em Pedagogia

${ }^{2}$ Universidade Federal de Sergipe, Departamento de Educação, Curso de Graduação em Pedagogia

${ }^{3}$ Universidade do Estado da Bahia, Departamento de Educação, Curso de Graduação em Pedagogia ORCID ID: https://orcid.org/0000-0001-9565-8785*

ORCID ID: https://orcid.org/0000-0002-5562-0085**

ORCID ID: https://orcid.org/0000-0001-7981-9091**

\begin{abstract}
In this article we carried out a systematic review of the specific literature on gender, published in Tempos e Espaços em Educação Journal between 2014 and 2019. The emphasis was on the methodological process that produced the different results found in the studies, based on the methodology of systematic review. Based on the selection of variables and inclusion/exclusion criteria, it was found that the specific gender literature published in Tempos e Espaços em Educação Journal suggests a significant expansion in the scientific production of gender studies, contributing to the destabilization of norms, classifications and hierarchies in the field of Education.
\end{abstract}

\section{Keywords}

Gender. Systematic review. Tempos e Espaços em Educação Journal.

\section{Os estudos de gênero na Revista Tempos e Espaços em Educação:}

\section{Resumo}

\section{uma revisão sistematizada}

Realiza-se uma revisão sistematizada da literatura específica sobre gênero publicada na Revista Tempos e Espaços em Educação no período de 2014 a 2019. A ênfase se deu no processo metodológico que produziu os diferentes resultados encontrados nos estudos segundo a metodologia de revisão sistematizada. Verificou-se, a partir da seleção de variáveis e de critérios de inclusão/exclusão, que a literatura específica sobre gênero publicada no referido periódico sugere significativa ampliação na produção científica dos estudos de gênero, contribuindo para a desestabilização de normatizações, classificações e hierarquizações no campo da educação.

\section{Palavras-chave}

Gênero. Revisão sistematizada. Revista Tempos e Espaços em Educação. 


\title{
Estudios de género en la Revista Tempos e Espaços em Educação:
} una revisión sistemática

\begin{abstract}
Resumen
Se realizó una revisión sistemática de la literatura específica de género publicada en la Revista Tempos e Espaços em Educação de 2014 a 2019. El énfasis se situó en el proceso metodológico que produjo los diferentes resultados encontrados en los estudios de acuerdo con la metodología de revisión sistemática. Se encontró, con base en la selección de variables y criterios de inclusión / exclusión, que la literatura específica sobre género publicada en esa revista sugiere una expansión significativa en la producción científica de estudios de género, contribuyendo a la desestabilización de las normas, clasificaciones y jerarquías en el campo de la educación.
\end{abstract}

\section{Palabras clave}

Género. Revisión sistemática. Revista Tempos e Espaços em Educação.

\section{Introduction}

We have observed a significant increase in scientific production about gender and sexuality in the last decade in several fields of knowledge, specifically in the field of Education. These studies have in common the fact that they suggest that serious discussion about these themes contributes to destabilize norms, classifications and hierarchies (DIAS; AMORIM, 2015; DIAS; OLIVEIRA, 2015; DIAS; OLIVEIRA; SANTOS, 2018; RIOS; CARDOSO; DIAS, 2018).

In the face of the volume of studies discussing gender issues that are published in scientific journals focusing on the dissemination of reports about Education research, we evidence the need to socialize, within the academic community of the field, overviews that highlight the advances and the theory gaps regarding the theme. Among the methodological alternatives to achieve that purpose, Dias and Amorim (2015) and Dias, Oliveira and Santos (2018) point to the systematic review of literature.

For this investigation, we used, as a database, Tempos e Espaços de Educação Journal (REVTEE, in Portuguese), in its online version ${ }^{1}$, a quarterly journal edited by the Postgraduate Program in Education of the Federal University of Sergipe. REVTEE started to be traditionally published in 2010 and in 2014 the journal started to be published online.

1 Available at: https://seer.ufs.br/index.php/revtee/index. Accessed on: Feb. 10, 2020. ISSN: 2358-1425.

Educação \& Formação, Fortaleza, v. 5, n. 14, p. 150-175, maio/ago. 2020

DOI: https://doi.org/10.25053/redufor.v5i14mai/ago.2495in

http://seer.uece.br/redufor 
This journal publishes academic-scientific articles, promoting and facilitating academic exchange nationally and internationally, aimed at teachers, students and researchers in Human Science fields, with an emphasis on Education studies.

Exploring the numbers and volumes of REVTEE, we notice a significant number of articles focused on emerging themes on the connection between gender and Education. In this sense, the following research question emerged: what advances and theory gaps regarding researches focused on gender issues can the systematization of studies published in REVTEE reveal? In the face of that question, we outlined the following objectives: identifying specific literature about gender in REVTEE; analyzing the contributions of the studies found for the connection between gender and Education; pointing to possible theory gaps regarding that theme. For that end, we organized this text in two parts: the first describes the process of systematic review; and the second presents the discussion of the results.

\section{The process of systematic review}

Systematic review of literature consists of a research approach that has been explored more frequently in the last ten years, due to the need to describe what has already been produced regarding a specific theme, as well as "[...] verifying gaps in the data in order to guide new studies on the theme" (SANTOS; SILVA, 2018, p. 142, our translation).

According to Silva and Mercado (2019, p. 51, our translation), this type of study "[...] is commonly based on the analysis of a survey that seeks to improve the understanding of the analyzed issue". Thus, initially it is necessary to gather a group of studies already published about the analyzed theme and then systematization takes place. During systematization, one shouldn't "[...] simply gather information, but realize how that information is being used" (SANTOS; SILVA, 2018, p. 142, our translation).

In the Education field, specifically, systematic review contributes to "[...] concentrate results from several other studies in one paper, increasing reliability and revealing the status of a research problem" (DIAS; AMORIM, 2015, p. 196, our translation). Considering the potential of this research approach, in this study, we chose to use the plan

Educação \& Formação, Fortaleza, v. 5, n. 14, p. 150-175, maio/ago. 2020 
developed by Cooper (2010), already explored in the Political Science field (FIGUEIREDO FILHO et al., 2014).

This research plan is organized in seven stages: a) identification and formulation of the research problem; b) gathering literature (in this case, surveying the articles in REVTEE); c) collecting data on each study; d) evaluation of the quality of the studies; e) analysis and summary of the studies' results; f) interpretation of collected data; and g) presentation of results.

To gather literature, that is, to delimit the material that will be systematized, it is necessary to define exclusion/inclusion criteria. In this research, we used the following exclusion/inclusion criteria: a) the article must have been published in REVTEE between 2014 and 2019 (after the journal started to be published online); b) the article could be in any language; c) the word "gender" should be present in the title, in the abstract or in the keywords.

After defining exclusion/inclusion criteria, we carried out data collection for each study and evaluated its relevance based on titles, abstracts and keywords. Once data collection was done, we proceeded to the analysis, summary and discussion of collected data, according to the plan proposed by Cooper (2010). The results and discussion about the data collected are presented next.

\section{Results and discussion}

We analyzed 21 editions and 409 articles published between 2014 and 2019 in REVTEE. Based on the exclusion/inclusion criteria, we selected 40 articles that focused on issues emerging from the connection between gender and Education. These articles represent about $10 \%$ of the total number of studies published by REVTEE in the time frame chosen for this analysis. Table 1 shows the studies that were selected. 
Table 1 - Articles selected

\begin{tabular}{|c|c|c|c|c|}
\hline Author & $\begin{array}{c}\text { Title } \\
\end{array}$ & V. & N. & Year \\
\hline $\begin{array}{lll}\text { RODRIGUES, } & \text { D. } & \text { S.; } \\
\text { FARO, L. C. A. } & \end{array}$ & $\begin{array}{l}\text { Entre fronteiras semoventes: a constituição do } \\
\text { feminino das filhas de lemanjá }\end{array}$ & 12 & 29 & 2019 \\
\hline $\begin{array}{l}\text { SILVA JUNIOR, P. M.; } \\
\text { IVENICKI, A. }\end{array}$ & $\begin{array}{l}\text { Entre sexualidades, masculinidades e raça: contribuições } \\
\text { do multi/interculturalismo para a prática pedagógica }\end{array}$ & 12 & 29 & 2019 \\
\hline GUZZI, J. & $\begin{array}{l}21 \text { gramos: el amor como epifenómeno de la tensión } \\
\text { cuerpo-alma }\end{array}$ & 12 & 29 & 2019 \\
\hline DONATO, A.; TONELLI, L. & A resistência do corpo & 12 & 28 & 2019 \\
\hline CARDOSO, H. M. & $\begin{array}{l}\text { Gênero, sexualidade e escola: contribuições da } \\
\text { teorização de Foucault }\end{array}$ & 11 & 1 & 2019 \\
\hline $\begin{array}{lll}\text { SANTOS, } & \text { A. } & \text { C.; } \\
\text { FELDENS, D. G. } & \end{array}$ & $\begin{array}{l}\text { Vozes do triunfo: narrativas de si de professoras da } \\
\text { educação básica }\end{array}$ & 11 & 1 & 2019 \\
\hline $\begin{array}{l}\text { SILVA, } \quad \text { M. } \quad \text { M. } \quad \text { T.; } \\
\text { TAVARES, C. }\end{array}$ & $\begin{array}{l}\text { Mulheres na luta: participação de mulheres nas } \\
\text { ocupações de } 2016 \text { na Universidade Federal de } \\
\text { Pernambuco }\end{array}$ & 11 & 27 & 2018 \\
\hline DUBET, F. & A escola "embaraçada" com a educação mista & 11 & 25 & 2018 \\
\hline $\begin{array}{l}\text { KAPLAN, C. V.; XAVIER, } \\
\text { N. R. }\end{array}$ & $\begin{array}{l}\text { As infâncias na literatura latino-americana: quais os } \\
\text { lugares da menina e da mulher negras? }\end{array}$ & 11 & 25 & 2018 \\
\hline $\begin{array}{l}\text { DIAS, A. F.; MENEZES, } \\
\text { C. A. A. }\end{array}$ & $\begin{array}{l}\text { Que inovação pedagógica a pedagogia queer propõe } \\
\text { ao currículo escolar? }\end{array}$ & 10 & 23 & 2017 \\
\hline $\begin{array}{l}\text { COUTO, A. S.; CRUZ, M. } \\
\text { H. S. }\end{array}$ & $\begin{array}{l}\text { Inserção de gênero no currículo de História e a } \\
\text { formação para o trabalho docente }\end{array}$ & 10 & 23 & 2017 \\
\hline ALMEIDA, W. R. A. & Uniforme escolar e uniformização dos corpos & 10 & 22 & 2017 \\
\hline $\begin{array}{l}\text { PINTO, É. } \\
\text { CARVALHO, J. } \\
\text { RABAY, G. }\end{array}$ & As relações de gênero nas escolhas de cursos superiores & 10 & 22 & 2017 \\
\hline $\begin{array}{l}\text { ARAÚJO, E.; BARROS, } \\
\text { V. }\end{array}$ & $\begin{array}{l}\text { "Modo Deadline": uma análise sobre o tempo das } \\
\text { mulheres académicas }\end{array}$ & 10 & 22 & 2017 \\
\hline $\begin{array}{l}\text { SANTOS, É. S.; LAGE, A. } \\
\text { C. }\end{array}$ & $\begin{array}{l}\text { Gênero e diversidade sexual na educação básica: um } \\
\text { olhar sobre o componente curricular Direitos Humanos } \\
\text { e Cidadania da rede de ensino de Pernambuco }\end{array}$ & 10 & 22 & 2017 \\
\hline DIAS, A. F. et al. & Schooling and subversions of gender & 10 & 22 & 2017 \\
\hline GALAK, E. & $\begin{array}{l}\text { Pedagogías del cuerpo y del carácter en la "Revista de } \\
\text { Educación" durante la gobernación de José Luís } \\
\text { Cantilo (Buenos Aires, 1922-1926) }\end{array}$ & 10 & 21 & 2017 \\
\hline $\begin{array}{l}\text { CARVALHO, M. E. P. et } \\
\text { al. }\end{array}$ & $\begin{array}{l}\text { Origins and challenges of gender studies centers in } \\
\text { higher education in NorthERN and Northeastern Brazil }\end{array}$ & 10 & 21 & 2017 \\
\hline $\begin{array}{l}\text { FRANÇA, F. } \quad \text { G. } \\
\text { FERRARI, A. }\end{array}$ & $\begin{array}{l}\text { Mais do que professores/as, professores/as } \\
\text { homossexuais na escola }\end{array}$ & 9 & 20 & 2016 \\
\hline SANTANA, J. V. J. et al. & $\begin{array}{l}\text { Constituindo gêneros: sobre a produção de } \\
\text { masculinidades e feminilidades na educação infantil }\end{array}$ & 9 & 20 & 2016 \\
\hline $\begin{array}{l}\text { COSTA, P. R. S. M.; } \\
\text { MACARRO, M. J. M. }\end{array}$ & $\begin{array}{l}\text { Los aspectos educativos de la Ley Orgánica } 01 / 2004 \\
\text { de } 28 \text { de diciembre, de medidas de protección integral } \\
\text { contra la violencia de género }\end{array}$ & 9 & 20 & 2016 \\
\hline $\begin{array}{l}\text { PREINFALK- } \\
\text { FERNÁNDEZ, M. L. }\end{array}$ & $\begin{array}{l}\text { La educación sexual en el sistema educativo formal } \\
\text { costarricense }\end{array}$ & 9 & 19 & 2016 \\
\hline $\begin{array}{l}\text { PORTO, R.; GALVÃO, F. } \\
\text { D. }\end{array}$ & $\begin{array}{l}\text { De Slutwalk à Marcha das Vadias: o imperativo dos } \\
\text { feminismos em Natal (RN) }\end{array}$ & 9 & 19 & 2016 \\
\hline $\begin{array}{l}\text { BECKER, S.; OLIVEIRA, } \\
\text { E. A. }\end{array}$ & $\begin{array}{l}\text { Educação e direitos para (in)humanos? Desafios e } \\
\text { reflexões sobre os dilemas de LGBTs perante o } \\
\text { discurso jurídico brasileiro }\end{array}$ & 9 & 19 & 2016 \\
\hline RODRIGUES, L. & $\begin{array}{l}\text { Transgredir para empoderar: o empoderamento das } \\
\text { jovens mulheres pela educação }\end{array}$ & 9 & 18 & 2016 \\
\hline
\end{tabular}

Educação \& Formação, Fortaleza, v. 5, n. 14, p. 150-175, maio/ago. 2020

DOI: https://doi.org/10.25053/redufor.v5i14mai/ago.2495in

http://seer.uece.br/redufor 
Table 1 - Articles selected

\begin{tabular}{|c|c|c|c|c|}
\hline Autor & Título & V. & N. & Ano \\
\hline $\begin{array}{l}\text { MORAIS, A. B. A.; } \\
\text { CARVALHO, M. E. P. }\end{array}$ & $\begin{array}{l}\text { Institucionalização dos estudos de gênero na } \\
\text { universidade: uma análise a partir de narrativas de } \\
\text { acadêmicas feministas }\end{array}$ & 8 & 17 & 2015 \\
\hline $\begin{array}{l}\text { EUGÊNIO, B. G.; LIMA, A. } \\
\text { O. }\end{array}$ & $\begin{array}{l}\text { Imagens de negros e negras no livro didático de } \\
\text { História dos anos iniciais do ensino fundamental }\end{array}$ & 8 & 16 & 2015 \\
\hline $\begin{array}{l}\text { VIEIRA, C. M.; COELHO, } \\
\text { M. A. }\end{array}$ & $\begin{array}{l}\text { Sexualidade e deficiência intelectual: concepções, } \\
\text { vivências e o papel da educação }\end{array}$ & 7 & 14 & 2014 \\
\hline CRUZ, M. H. S. & $\begin{array}{l}\text { A crítica feminista à ciência e contribuição à pesquisa } \\
\text { nas Ciências Humanas }\end{array}$ & 7 & 12 & 2014 \\
\hline $\begin{array}{l}\text { THÜRLER, } \\
\text { SANTOS, J. L. }\end{array}$ & $\begin{array}{l}\text { Um debate sobre a escola como tecnologia político- } \\
\text {-cultural }\end{array}$ & 7 & 12 & 2014 \\
\hline SARAT, M.; CAMPOS, M. I. & Gênero, sexualidade e infância: (con)formando meninas & 7 & 12 & 2014 \\
\hline FERREIRA, M. M. & $\begin{array}{l}\text { Relações de classe e gênero na escola: revisitando } \\
\text { conceitos de igualdade, desigualdade, diferença, } \\
\text { classe e gênero }\end{array}$ & 7 & 12 & 2014 \\
\hline $\begin{array}{l}\text { ANJOS, J.P.; CARDOSO, } \\
\text { L. R. }\end{array}$ & Hanami ou corpos fogem, vazam, escapam... & 7 & 12 & 2014 \\
\hline $\begin{array}{l}\text { DI GREGORIO, M. F.; } \\
\text { SILVA, K. N. }\end{array}$ & $\begin{array}{l}\text { Gênero e sexualidade no lócus família/escola: } \\
\text { incursões deflagradas à não heterossexualidade e os } \\
\text { desafios para a cidadania reconhecida }\end{array}$ & 7 & 12 & 2014 \\
\hline $\begin{array}{lll}\text { CANOTILHO, } & \text { A. } & \text { P.; } \\
\text { ARAUJO, N. } & \text { F.; } & \text { DE } \\
\text { OLIVEIRA, S. M. T. } & \end{array}$ & $\begin{array}{l}\text { A contribuição da escola para a emancipação das } \\
\text { mulheres }\end{array}$ & 7 & 12 & 2014 \\
\hline DIAS, A. F. & $\begin{array}{l}\text { Como as escolas educam corpos nas práticas } \\
\text { pedagógicas? }\end{array}$ & 7 & 12 & 2014 \\
\hline DE SOUZA, L. P. & $\begin{array}{l}\text { Educação, gênero e raça: mapeando algumas } \\
\text { desigualdades }\end{array}$ & 7 & 12 & 2014 \\
\hline SILVA, M. A. C. & $\begin{array}{l}\text { Formação docente: do infinito ao particular! Narrativas } \\
\text { sobre gênero, raça e religião }\end{array}$ & 7 & 12 & 2014 \\
\hline SANTANA, A. M. & Gênero, sexualidade e educação: perspectivas em debate & 7 & 12 & 2014 \\
\hline BOGOSSIAN, T. & $\begin{array}{l}\text { “Já pensou Pedro com um cabelão de Maria } \\
\text { Chiquinha! Não combina, né?!". Geografia e gênero na } \\
\text { educação infantil }\end{array}$ & 7 & 12 & 2014 \\
\hline
\end{tabular}

Source: Prepared by the authors (2019).

After defining the literature, we carried out, in a second recursive movement, data collection on each selected study. In this data collection, we evaluated titles, abstracts and keywords (COOPER, 2010). In this research movement, we highlighted the methodological approaches used more and less frequently in these studies. As a result from that procedure, it is possible to verify the categorization indicated in Table 2. 
Table 2 - Methodological approaches used in selected studies

\begin{tabular}{|l|l|}
\hline \multicolumn{1}{|c|}{ Approach } & \multicolumn{1}{c|}{ Study } \\
\hline Filmic analysis & Anjos and Cardoso (2014); Guzzi (2019) \\
\hline Image analysis & Almeida (2017) \\
\hline Narrative analysis & $\begin{array}{l}\text { França and Ferrari (2016); Morais and Carvalho (2015); Santana } \\
\text { (2014); Santos and Feldens (2019) }\end{array}$ \\
\hline (Auto)Biography, life story & Carvalho et al. (2017); Sarat and Campos (2014); Silva (2014) \\
\hline Essays/Bibliographical research & $\begin{array}{l}\text { Bogossian (2014); Canotilho, Araujo and Oliveira (2014); Cardoso } \\
\text { (2019); Cruz (2014); Dias (2014); Dias and Menezes (2018); Dias et al. } \\
\text { (2017); Donato and Tonelli (2019); Dubet (2018); Ferreira (2014); } \\
\text { Kaplan and Xavier (2018); Preinfalk-Fernández (2016); Santana et al. } \\
\text { (2016); Thürler and Santos (2014); Vieira and Coelho (2014) }\end{array}$ \\
\hline Compared studies & Kaplan and Xavier (2018) \\
\hline Field research & $\begin{array}{l}\text { Araújo and Barros (2017); Couto and Cruz (2017); Di Gregorio and } \\
\text { Silva (2014); Rodrigues and Faro (2019); Silva and Tavares (2019) }\end{array}$ \\
\hline Document research & $\begin{array}{l}\text { Becker and Oliveira (2016); Costa and Macarro (2016); Galak (2017); } \\
\text { Rodrigues (2016); Santos and Lage (2017); Souza (2014) }\end{array}$ \\
\hline Action research & Silva Junior and Ivenicki (2019) \\
\hline Quanti-qualitative research & Pinto, Carvalho and Rabay (2017) \\
\hline Online research & Porto and Galvão (2016) \\
\hline Exploratory research & Eugênio and Lima (2015) \\
\hline & Source: Prepared by the authors (2019). \\
\hline
\end{tabular}

Table 2 evidences a multitude of approaches with which gender issues have been analyzed from an investigative point of view in the context of studies published in REVTEE. However, we observe that there is a tendency toward the exploration of narrative analysis, essays/bibliographical research, field research and document research. Among these, 15 studies used essay/bibliographical research, which corresponds to $37.5 \%$ of the researched sample.

Subsequently, we carried out the analysis, summary and interpretation of studies. Based on these analysis movements, the following categories emerged: a) Gender and sexuality as constraints in the individuals' professionalization; b) Multiculturalism and intersectional studies; c) Gender and body norms; d) Contributions by thinkers/theories for gender studies; e) Concepts about women and their social role in contemporaneity; f) Gender, sexuality and curriculum; and g) Gender, disabled people, childhood and family. We will discuss these categories next. 


\section{a) Gender and sexuality as constraints in the individuals' professionalization}

Out of the 40 studies selected, four (10\%) worried about investigating, centrally, the implications of gender and sexuality in individuals' professional referrals and paths. Dubet (2018, p. 9, our translation), for example, worried about "[...] explaining the paradox that, although girls have better school results than boys, they turn to the less profitable careers, which lead them to less favorable professional positions than those of boys".

To this respect, according to data from the Brazilian Institute of Geography and Statistics (IBGE, in Portuguese), currently, women earn less than men in all professional fields. These data were revealed through the 2018 National Household Sample Survey (Continuous PNAD), which, in addition, highlighted that this discrepancy is intensified for women between 40 and 49 years of age, who earn salaries corresponding to $79.4 \%$ of the salaries earned by men in the same job (IBGE, 2019).

The epistemological unrest that emerged from the awareness concerning the implications of that social inequality led Pinto, Carvalho and Rabay (2017, p. 47, our translation) to analyze "[...] how gender relations condition Higher Education choices for High School students". Through that study, those authors verified that this choice doesn't happen randomly, but is conditioned by multiple variables that define specific social roles for women and different specific social roles for men.

Sarat and Campos (2014, p. 45, our translation) analyzed the "[...] trajectories of two Pedagogy professors from a public university located in the countryside of the CentralWest Region". Based on those analyses, the authors attempted to understand how these university professors "[...] experienced/built concepts of gender and sexuality in their different interpersonal relationships, in private and public spaces, since they were educated and brought up to correspond to the 'so-called' girl behaviors" (SARAT; CAMPOS, 2014, p. 45 , our translation).

When the issue of the feminine condition is added to a sexual orientation that openly deviates from the norm, we observe the combination of socially excluding mechanisms. In this sense, França and Ferrari (2016, p. 41, our translation) worried about problematizing the ways in which teachers constitute themselves as LGBT+ educators and 
discussing how they "[...] are constructed in power relations, in interpersonal relations and, overall, how they connect with others and with the school institution".

Gender inequality between men and women, evidenced through studies such as those by Dubet (2018), Sarat and Campos (2014) and Pinto, Carvalho and Rabay (2017), in a sexist society, goes hand in hand with the argument to gradually exclude and marginalize individuals who manifest any behavior associated to a deviant sexuality. The study by França and Ferrari (2016) evidences the difficulties and the daily struggle for openly LGBT+ teachers to ascend and stay in that profession.

\section{b) Multiculturalism and intersectional studies}

In a second line of investigation, it is possible to group the studies by Eugênio and Lima (2015), Ferreira (2014), Kaplan and Xavier (2018), Rodrigues and Faro (2019), Silva (2014), Silva Junior and Ivenicki (2019) and Souza (2014). Seven studies constitute this category, which represents $17.5 \%$ of the selected studies. They share their concern with the implications that the intersection of social markers such as gender, race, religion or social class have on the development of individuals.

Studies such as those by Ferreira (2014), Silva (2014) and Souza (2014) consist of theoretical essays that endeavored to raise awareness of the characteristics of our society and how its issues of difference, inequality, identity, race, class, gender, religion mark the construction of individuals' identities, including men. In this sense, Silva Junior e Ivenicki (2019, p. 125, our translation) focused on "[...] how multiculturalism can offer resources to handle issues of sexualities, race, masculinities and social class in the classroom".

Within a contemporary approach and shedding light on a little explored locus of educational research, Rodrigues and Faro (2019) sought to understand the non-school processes that contribute to the identity construction of daughters and sons of lemanjá. In this case, the study points to fields of research that transcend the scope of formal education institutions, but in which there are mechanisms that support the development, learning, training and freedom of individuals. 
Kaplan and Xavier (2018, p. 111, our translation) sought "[...] to understand the different childhoods that exist". To that end, they took the autobiographical narratives of Black women from three countries (Brazil, Argentina and Uruguay), about their childhoods. By giving voice to Black women, the authors begin to legitimize singular epistemologies that aren't traditional in the field of Education research and of general science. In the opposite movement, Eugênio and Lima (2015) evidenced, through the analysis of History textbooks for Elementary School that discuss issues concerning Black people, that the books that do discuss the theme do so from a masculine and European point of view.

These summaries evidence the need to subvert these epistemologies so that individuals get to tell their stories (FREIRE, 2018). Education, as an empowering tool, is deeply connected to how it is conceived and offered; in this sense, we evidence the urgency of widespread liberating education, of education as a practice of freedom (HOOKS, 2013).

\section{c) Gender and body norms}

Studies such as those by Almeida (2017), Anjos and Cardoso (2014), Cardoso (2019), Dias (2014), Dias et al. (2017), Galak (2017), Guzzi (2019) and Thürler and Santos (2014) worried about problematizing the social norms that regulate bodies and oppress them in such a way that those who dare to disobey them may pay with their lives. These seven studies represent $17.5 \%$ of the total of selected articles.

When we deal with gender issues and their connection to the concept of body, we also deal with the concept of norm. These norms are presented in the most common ornaments, as highlighted by Almeida (2017, p. 9, our translation), who noticed the "[...] school uniform as an essential aspect to understand the school universe and the culture that sustains and defines it". The school uniform is only one of the countless control mechanisms used to standardize bodies, as Guzzi (2019) highlights when analyzing the movie 21 Gramos, released in 2003 and directed by the Mexican director Alejandro González Iñárritu. Also from the perspective of filmic analysis, Anjos and Cardoso (2014) analyzed the movie Cherry blossoms - Hanami, released in 2007 and directed by Doris Dörrie, and problematized the stability of discursive norms of "sex". 
Cardoso (2019, p. 322, our translation) highlights that "[...] there is a process that produces normalization mechanisms, which separates 'normal' and 'abnormal' individuals". Among the institutions where this process is more noticeable, we highlight the school. It is one of the main " [...] institutions that act on the production of the modern individual, the normalized individual, through the disciplinary procedures used by it" (CARDOSO, 2019, p. 322, our translation). Thus, education has an essential role. As part of a society that discriminates, produces and reproduces gender inequalities, it constitutes a generic space and, therefore, can reproduce the norm or contribute to subvert it.

The gender norm is more clearly expressed when we use the case of Physical Education as an example. According to Donato and Tonelli (2019, p. 49, our translation), "[...] through the practices of knowledge and power of Physical Education over the body, there is a desubjectivation, within which conducts, behaviors and habits end up naturalized". In the activities developed during Physical Education classes, it is common to separate boys and girls. This kind of segregation is based on the concept that each sex has appropriate activities. At the limit, there is a model that functions in the sense of "[...] educating boys' and girls' bodies to produce differences" (DIAS, 2014, p. 105 , our translation).

In this sense, regarding this concern with the regulation of bodies and the production of differences, authors such as Dias et al. (2017), Galak (2017) and Thürler and Santos (2014) invested in theoretical essays and document research in order to point to alternatives for the subversion of gender norms in the search for a liberating education (FREIRE, 2018), an education genuinely expressed as a practice for freedom (HOOKS, 2013).

\section{d) Contributions by thinkers/theories for gender studies}

Among the selected studies, we highlight the concern of authors who have, as study objects, thinkers or theories that have contributed to the advancement of studies on gender issues. As for this category, we can mention studies such as those by Becker and Oliveira (2016), Cardoso (2019), Cruz (2014), Dias and Menezes (2018) and Silva 
Junior and Ivenicki (2019). There are five studies, which represents $12.5 \%$ of the total of selected articles.

In this category, it is possible to highlight the study by Cardoso $(2019$, p. 319 , our translation), which had as an object "[...] the contribution of Michael Foucault's theories to the discussion about gender, sexuality and education"; the study by Silva Junior and Ivenicki (2019, p. 125, our translation), who investigated "[...] how multiculturalism can offer resources to handle issues on sexualities, race, masculinities and social class in the classroom"; the study by Dias e Menezes (2018, p. 37, our translation), who problematized "[...] the potentialities of queer pedagogy and curriculum in school"; the study by Becker and Oliveira (2016, p. 163, our translation), who endeavored to deconstruct the gender category in Law Maria da Penha, "[...] in the deleuzian/Guattarian sense"; as well as the study by Cruz (2014, p. 15, our translation), who investigated a "[...] feminist epistemology in science and research of Human and Social Sciences, particularly in the Education field".

The authors' investment in these studies converged in the sense of producing a theoretical body able to handle the phenomena emerging from the connection between gender and Education in the sense of a liberating education (FREIRE, 2018; HOOKS, 2013).

\section{e) Concepts about women and their social role in contemporaneity}

To constitute this category, we have the studies by Araújo and Barros (2017), Canotilho, Araujo and Oliveira (2014), Carvalho et al. (2017), Morais and Carvalho (2015), Sarat and Campos (2014), Porto and Galvão (2016), Santos and Feldens (2019) and Silva and Tavares (2019). These seven studies represent $17.5 \%$ of the total of studies selected and converge into a group of investigations that analyzed "[...] the discursive production about women in the contemporary school" (SANTOS; FELDENS, 2019 , p. 379, our translation) and beyond the school space. This material focused on the analysis of contemporary, empowered women, who, conscious of their oppressed condition, didn't acquiesce to the shackles that sexism wanted/wants to enforce upon them. This is the case, for example, of the study by Silva and Tavares (2019, p. 41, our translation), who "[...] analyzed the participation of women in occupations carried out in 
2016 in the Federal University of Pernambuco"; women who are part of the student movement, who raise their voices against injustice and fight for a more equal society.

These authors, problematizing the participation of university women in the student occupations of 2016, concluded that "[...] the experience of democratic practices and the environment that fosters discussion about human rights encourage potential transformation in practices and relationships" (SILVA; TAVARES, 2016, p. 41, our translation). In this sense, the occupations of 2016 constitute an important moment for female students to take the floor, state their point of view, act as the protagonists of a political process and identify with issues concerning feminism (FREIRE, 2018).

In the same line of thought, the study by Porto and Galvão (2016) presents the context of the "Slutwalk of the city of Natal", Rio Grande do Norte $(2011,2015)$, and signifies it as a political field that gave visibility to local feminisms that acted in that city and that state. Setting their sights on smaller movements, Araújo and Barros (2017, p. 173, our translation) analyzed "[...] some of the main traits in the use of time by female scholars, identifying some implications for academic and scientific politics on the institutional level". Similarly, Morais and Carvalho (2015, p. 235, our translation) analyzed, "[...] through the narratives of three feminist scholars from a federal university in the Northeast, their contributions to the institutionalization of gender studies".

Despite the advances identified, it is evident that combat to gender inequalities must resist and be intensified in order to produce an equal society. In this sense, studies such as those by Araújo and Barros (2017), Morais and Carvalho (2015), Porto and Galvão (2016) and Silva and Tavares (2019) depict fight scenarios that have, as protagonists, women in their movements of resistance and fight, who have also effected successful movements.

The first two studies depicted fight movements with broad national repercussion, and the other two, although not less important, emphasized the daily fight of women, who, in their professional actions, by not conforming to the reality imposed on them, fight for power with sexism and accumulate wins for the feminine cause. Paradoxically to that successful scenario, Canotilho, Araújo and Oliveira (2014, p. 91, our translation) shed a light on the "[...] hindrances in women's access to decision-making positions and the structures of formal democracy". A woman occupying a position of power in this 
sexist society is, in itself, a great challenge, but staying in those positions of power is a daily battle.

Carvalho et al. (2017, p. 163, our translation) focused on "[...] the trajectories of centers for gender studies affiliated to the Feminist Network of Gender Studies of the North/Northeast (REDOR, in Portuguese) and their founders". The last study in this category is by Sarat and Campos (2014, p. 45, our translation), who present "[...] reflections constructed in the trajectories of two Pedagogy professors from a public university located in the countryside of the Central-West Region". This study's concern corresponds to the concerns of aforementioned studies in this category, since it aimed to "[...] get to know and understand how [these women] experienced/built concepts of gender and sexuality in different interpersonal relationships, in private and public spaces" (SARAT; CAMPOS, 2014, p. 45, our translation).

This issue is justified because women who managed to resist the sexist oppression telling them daily that their place is at home, obeying a father, brother, husband, or similar, need to redouble their working strength to undertake work challenges inside and outside of their homes. According to Sarat and Campos (2014, p. 45, our translation), these women, as well as many others, "[...] were educated and brought up to correspond to "socalled' girl behaviors, according to dominant social and historical standards", who, although they dare to occupy work spaces outside the home, will continue to shoulder domestic tasks. It is because they don't conform to occupy the place of oppressed ad infinitum, but in a collective movement of awareness, that they have empowered themselves, gotten stronger, taken the floor and gained freedom (FREIRE, 2018).

\section{f) Gender, sexuality and curriculum}

The studies that helped us establish this category were those by Couto and Cruz (2017), Dias and Menezes (2018), Rodrigues (2016) and Santos and Lage (2017). It consists of four studies that focus on the presence of gender and sexuality issues in the Brazilian school curriculum and in the European school curriculum (RUDD; GOODSON, 2016; ULJENS, 2016). This corresponds to $10 \%$ of selected studies. 
These studies sought to "[...] identify, in the curriculum, the absence of gender" (COUTO; CRUZ, 2017, p. 249, our translation) or "[...] investigate what is indicated by course contents [...] concerning issues of gender and sexual diversity" (SANTOS; LAGE, 2017, p. 69 , our translation). These researches point to a concern with the presence and absence of themes related to gender issues in the school curriculum.

Dias and Menezes (2017, p. 37, our translation) used the "[...] potentialities of a queer pedagogy and curriculum in school" as an alternative for liberating education that values individuals in their highest potentialities. Through the curriculum, the school institution reveals and executes its way to see and think the world; the curriculum is also one of the ways in which government exercises biopower and governmentality (FOUCAULT, 1993). Based on that premise, "[...] othering the school curriculum is one of the innovations that queer pedagogy proposes to students and teachers today" (DIAS; MENEZES, 2017, p. 37, our translation).

By focusing the issue of the presence of themes concerning sexual education in Costa Rica's curriculum, Preinfalk-Fernández (2016, p. 103) traced an overview of the "[...] proceso histórico-evolutivo de la educación sexual en el sistema educativo costarricense". Costa and Macarro (2016, p. 111) presented an analysis "[...] de cómo el tema educativo se coloca en la Ley Orgánica 01/2004, de 28 de diciembre, que trata de las medidas de protección integral contra la violencia de género en España". Rodrigues (2016) investigated a report that was approved in September 2015 and was requested by the European Parliament to the Commission for Women's Rights and Gender Equality. This document intended to ensure democratic education and education for gender equality through the curriculum.

We verify in these three studies, which bring into view international documents and curriculum guidelines that handle gender issues, that, in this sense, global reality isn't that different from Brazilian reality, and the dispute between progressive and conservative education is present in curriculum debates worldwide.

According to Santos and Lage (2017, p. 69, our translation), there is silencing, for example, "[...] about transsexuality and the citizenship of trans people". According to Silva (2000, p. 89 , our translation), "[...] the difference isn't naturally occurring: it is discursively constructed". Therefore, it is through discourse that we produce and reproduce differences that may cause conflicts and destabilize traditional paradigms, 
because "[...] the values of western civilization themselves $[\ldots]$ are at risk when the gay lifestyle, for example, becomes a subject in the curriculum" (SILVA, 2000, p. 92, our translation).

\section{g) Gender, disabled people, childhood and family}

To constitute this category, contributed the studies by Bogossian (2014), Carvalho et al. (2017), Di Gregorio and Silva (2014), Kaplan and Xavier (2018), Santana (2014), Santana et al. (2016) and Vieira and Coelho (2014). These seven studies represent 17.5\% of the selected material, and emphasize the fact that gender is a category that encompasses any and all individuals.

Regarding this issue, Kaplan and Xavier (2018, p. 111, our translation), by collecting autobiographical narratives reminiscent of "[...] different childhoods that exist, described in three countries, Brazil, Argentina and Uruguay, between 1930 and 1940, formalized an understanding of the image of Black people designed by the writing of female authors". Here we emphasize the fact that these authors researched the childhood of Black girls based on their adult selves.

Santana et al. (2016, p. 63, our translation) sought to "[...] understand the connection between education, gender and sexuality and its repercussions to understand gender relations in the locus of Early Childhood Education". Bogossian (2014, p. 169, our translation) reflected on the "[...] gender inequality present at an Early Childhood Education institution in the city of Niterói, in the state of Rio de Janeiro". We observe that, although the three studies focused on the connection between childhood and gender issues, they didn't have children as participants.

Due to being immersed in a sexist society and living in contemporaneity with a conservative wave, carrying out researches on gender with children can lead to significant problems - during the investigation and beyond. This can be a reason for the fact that the studies analyzing the connections between gender and childhood didn't work with the children themselves.

This conservative wave and the far-right populism, on the rise worldwide, have as one of their consequences a hostile climate toward gender studies, which is directly reflected on the relationship between schools and families. In this sense, Di Gregorio and 
Silva (2014, p. 79 , our translation) point to "[...] possibilities of dialogue between the theme Education, Gender, Sexual Diversity and Human Rights in the locus of Family and School". The focus of these researchers is the "[...] non-heterosexual sexuality and its challenges since family guidance and the construction of gender identities in the school/social scenario" (DI GREGORIO; SILVA, 2014, p. 79, our translation). The same can be applied for the case reported by Santana (2014), who focused on the issue of the lesbian woman in the homosexual relationship.

Among the studies that constitute this category involving childhood, family and disabled people, the less frequent theme was the latter. Shedding light on the gender and sexuality issues of young intellectually disabled people, Vieira and Coelho (2014) didn't sugarcoat the fact that disabled people are also gendered people. The invisibilization of these individuals' gender and sexuality is a reflex of the invisibilization of these individuals as a whole. In order to overcome this scenario, a radical liberating education is paramount, an education as practice of freedom (FREIRE, 2018; HOOKS, 2013).

\section{Final considerations}

We verified that the scientific production that discussed gender issues in the context of REVTEE, between 2014 and 2019, evidenced that this theme, on its own, constitutes a social marker that conditions individuals' choices and professional careers, but that, when analyzed in intersection with issues of race, religion and class, potentializes dehumanizing ideologies that oppress, marginalize, exclude and invisibilize those whose bodies reveal traits that identify them as deviant from the norm.

On the other hand, we highlighted the presence of a countercurrent that has strengthened and empowered those who have been silenced. Some examples of this countercurrent are the street movements fighting for gender equality, such as the Slutwalk, and women's everyday fight against all forms, subtle and blatant, in which sexism is manifested.

We evidenced that, even in studies focused on the connection between gender and childhood, none of them considered the opinions of the children themselves. Likewise, school and family, as sister institutions in the commitment to children's development, when handling gender issues, due to aspects of a conservative moral 
base, have been rivals in antagonistic positions. In addition, little is discussed concerning "gender issues and disabled people". This scenario reveals a symptomatic picture of the rise of the conservative wave that insists on denying the existence of those who deviate from the norm.

In addition to the themes that were little discussed or that were discussed indirectly, we highlight the themes that weren't discussed in the selected studies, for example: the connection between gender and old age; policies for the prevention and treatment of HIV in formal and nonformal education environments; revenge porn in the school environment; the medicalization of deviant behaviors carried out since school; the polemics involving the use of public restrooms by trans people, besides so many other themes that lack investigation.

In this sense, it is possible to state that gender relations are understood as a social, historical and cultural construction, and school is one of the privileged spaces for this discussion. The studies selected point to original elements, be it the object itself, the investigation locus, the chosen theoretical framework, the methodological approach used, or the boldness with which results were presented.

Although still very far from an equal society, the studies systematized in this research indicate that the fight of all who feel first-hand the oppression against their gender has had some effect and that resistance must continue and become increasingly strong. In the convergence of these studies, we notice the urgency and necessity of the daily fight for public policies that support actions aimed at the construction of a society that combats any ideology that denies the humanity of human beings.

\section{References}

ALMEIDA, W. R. A. Uniforme escolar e uniformização dos corpos. Revista Tempos e Espaços em Educação, São Cristóvão, v. 10, n. 22, p. 9-22, 2017. Available at: https://seer.ufs.br/index.php/revtee/article/view/6134. Access on: Jan. 3, 2020. DOI: https://doi.org/10.20952/revtee.v10i22.6134. 
ANJOS, J. P.; CARDOSO, L. R. Hanami ou corpos fogem, vazam, escapam... Revista Tempos e Espaços em Educação, São Cristóvão, v. 7, n. 14, p. 69-78, 2014. Available at: https://seer.ufs.br/index.php/revtee/article/view/2953. Access on: Jan. 3, 2020. DOI: https://doi.org/10.20952/revtee.v0i0.2953.

ARAÚJO, E.; BARROS, V. "Modo Deadline": uma análise sobre o tempo das mulheres académicas. Revista Tempos e Espaços em Educação, São Cristóvão, v. 10, n. 22, p. 173186, 2017. Available at: https://seer.ufs.br/index.php/revtee/article/view/6440. Access on: Jan. 3, 2020. DOI: https://doi.org/10.20952/revtee.v10i22.6440.

BECKER, S.; OLIVEIRA, E. A. Educação e direitos para (in)humanos? Desafios e reflexões sobre os dilemas de LGBTs perante o discurso jurídico brasileiro. Revista Tempos e Espaços em Educação, São Cristóvão, v. 9, n. 19, p. 163-180, 2016. Available at: https://seer.ufs.br/index.php/revtee/article/view/5603. Access on: Jan. 3, 2020. DOI: https://doi.org/10.20952/revtee.v9i19.5603.

BOGOSSIAN, T. "Já pensou Pedro com um cabelão de Maria Chiquinha! Não combina, né?!". Geografia e gênero na educação infantil. Revista Tempos e Espaços em Educação, São Cristóvão, v. 7, n. 12, p. 169-186, 2014. Available at: https://seer.ufs.br/index.php/revtee/article/view/2963. Access on: Jan. 3, 2020. DOI: https://doi.org/10.20952/revtee.v0i0.2963.

CANOTILHO, A. P.; ARAUJO, N. F.; DE OLIVEIRA, S. M. T. A contribuição da escola para a emancipação das mulheres. Revista Tempos e Espaços em Educação, São Cristóvão, v. 7, n. 14, p. 91-102, 2014. Available at: https://seer.ufs.br/index.php/rev tee/article/view/2957. Access on: Jan. 3, 2020. DOI: https://doi.org/10.20952/revtee. v0i0.2957.

CARDOSO, H. M. Gênero, sexualidade e escola: contribuições da teorização de Foucault. Revista Tempos e Espaços em Educação, São Cristóvão, v. 11, n. 1, p. 319332, 2019. Available at: https://seer.ufs.br/index.php/revtee/article/view/9652. Access on: Jan. 3, 2020. DOI: https://doi.org/10.20952/revtee.v11i01.9652.

CARDOSO, H. M.; DIAS, A. F. Representações sobre corpo, gênero e sexualidades de estudantes das licenciaturas do Instituto Federal de Sergipe, campus Aracaju. Práxis Educacional, Vitória da Conquista, v. 13, n. 24, p. 76-94, 2016. Available at: http://periodicos2.uesb.br/index.php/praxis/article/view/930. Access on: Jan. 6, 2020. DOI: https://doi.org/10.22481/praxis.v13i24.930.

CARVALHO, M. E. P. et al. Origins and challenges of gender studies centers in higher education in NorthERN and Northeastern Brazil. Revista Tempos e Espaços em Educação, São Cristóvão, v. 10, n. 21, p. 163-176, 2017. Available at: https://seer.ufs.br/index.php/revtee/article/view/6340. Access on: Jan. 3, 2020. DOI: https://doi.org/10.20952/revtee.v10i21.6340. 
COOPER, H. Research synthesis and meta-analysis: a step-by-step approach. 3. ed. Thousand Oaks: Sage, 2010.

COSTA, P. R. S. M.; MACARRO, M. J. M. Los aspectos educativos de la Ley Orgánica $01 / 2004$ de 28 de diciembre, de medidas de protección integral contra la violencia de género. Revista Tempos e Espaços em Educação, São Cristóvão, v. 9, n. 20, p. 111-120, 2016. Available at: https://seer.ufs.br/index.php/revtee/article/view/5900. Access on: Jan. 3, 2020. DOI: https://doi.org/10.20952/revtee.v9i20.5900.

COUTO, A. S.; CRUZ, M. H. S. Inserção de gênero no currículo de História e a formação para o trabalho docente. Revista Tempos e Espaços em Educação, São Cristóvão, v. 10, n. 23, p. 249-262, 2017. Available at: https://seer.ufs.br/index.php/revtee/article/ view/6764. Access on: Jan. 3, 2020. DOI: https://doi.org/10.20952/revtee.v10i23.6764.

CRUZ, M. H. S. A crítica feminista à ciência e contribuição à pesquisa nas Ciências Humanas. Revista Tempos e Espaços em Educação, São Cristóvão, v. 7, n. 14, p. 15-28, 2014. Available at: https://seer.ufs.br/index.php/revtee/article/view/2949. Access on: Jan. 3, 2020. DOI: https://doi.org/10.20952/revtee.v0i0.2949.

DIAS, A. F. Como as escolas educam corpos nas práticas pedagógicas?. Revista Tempos e Espaços em Educação, São Cristóvão, v. 7, n. 12, p. 103-112, 2014. Available at: https://seer.ufs.br/index.php/revtee/article/view/2958. Access on: Jan. 3, 2020. DOI: https://doi.org/10.20952/revtee.v0i0.2958.

DIAS, A. F. et al. Schooling and subversions of gender. Revista Tempos e Espaços em Educação, São Cristóvão, v. 10, n. 22, p. 83-92, 2017. Available at: https://seer.ufs.br/index.php/revtee/article/view/6433. Access on: Jan. 3, 2020. DOI: https://doi.org/10.20952/revtee.v10i22.6433.

DIAS, A. F.; AMORIM, S. Body, gender and sexuality in teacher training: a metaanalysis. Educação em Revista, Curitiba, n. 56, p. 193-206, 2015. Available at: http://www.scielo.br/scielo.php?script=sci_arttext\&pid=S0104-40602015000200193\&lng= en\&nrm=iso. Access on: Jan. 6, 2020. DOI: http://dx.doi.org/10.1590/0104-4060.40998.

DIAS, A. F.; MENEZES, C. A. A. Que inovação pedagógica a pedagogia queer propõe ao currículo escolar?. Revista Tempos e Espaços em Educação, São Cristóvão, v. 10, n. 23, p. 37-48, 2017. Available at: https://seer.ufs.br/index.php/revtee/article/view/ 7443. Access on: Jan. 3, 2020. DOI: https://doi.org/10.20952/revtee.v10i23.7443.

DIAS, A. F.; OLIVEIRA, D. A. As abordagens de corpo, gênero e sexualidades no projeto político-pedagógico em um Colégio Estadual de Aracaju, SE. Holos, Natal, v. 3, p. 259271, 2015. Available at: https://doi.org/10.22478/ufpb.2359-7003.2018v27n2.24814. Access on: 10 jan. 2020. Available at: http://www2.ifrn.edu.br/ojs/index.php/holos/ar ticle/view/3084. Access on: Jan. 6, 2020. DOI: https://doi.org/10.15628/holos.2015.3084.

Educação \& Formação, Fortaleza, v. 5, n. 14, p. 150-175, maio/ago. 2020

DOI: https://doi.org/10.25053/redufor.v5i14mai/ago.2495in

http://seer.uece.br/redufor 
DIAS, A. F.; OLIVEIRA, D. A.; SANTOS, M. S. Uma revisão sistematizada da produção do conhecimento sobre corpo, gênero, sexualidades na educação. Revista Temas em Educação, João Pessoa, v. 27, n. 2, p. 119-133, 2018. Available at: https://doi.org/10.22478/ufpb.2359-7003.2018v27n2.24814. Access on: Jan. 10, 2020.

DI GREGORIO, M. F.; SILVA, K. N. Gênero e sexualidade no lócus família/escola: incursões deflagradas à não heterossexualidade e os desafios para a cidadania reconhecida. Revista Tempos e Espaços em Educação, São Cristóvão, v. 7, n. 12, p. 7990, 2014. Available at: https://seer.ufs.br/index.php/revtee/article/view/2954. Access on: Jan. 3, 2020. DOI: https://doi.org/10.20952/revtee.v0i0.2954.

DONATO, A.; TONELLI, L. A resistência do corpo. Revista Tempos e Espaços em Educação, São Cristóvão, v. 12, n. 28, p. 49-62, 2019. Available at: https://seer.ufs.br/index.php/revtee/article/view/10164. Access on: Jan. 3, 2020. DOI: https://doi.org/10.20952/revtee.v12i28.10164.

DUBET, F. A escola "embaraçada" com a educação mista. Revista Tempos e Espaços em Educação, São Cristóvão, v. 11, n. 25, p. 9-20, 2018. Available at: https://seer.ufs.br/index.php/revtee/article/view/8379. Access on: Jan. 3, 2020. DOI: https://doi.org/10.20952/revtee.v11i25.8379.

EUGÊNIO, B. G.; LIMA, A. O. Imagens de negros e negras no livro didático de História dos anos iniciais do ensino fundamental. Revista Tempos e Espaços em Educação, São Cristóvão, v. 8, n. 16, p. 247-256, 2015. Available at: https://seer.ufs.br/index.php/rev tee/article/view/3964. Access on: Jan. 3, 2020. DOI: https://doi.org/10.20952/revtee.v0i0. 3964.

FERREIRA, M. M. Relações de classe e gênero na escola: revisitando conceitos de igualdade, desigualdade, diferença, classe e gênero. Revista Tempos e Espaços em Educação, São Cristóvão, v. 7, n. 14, p. 57-68, 2014. Available at: https://seer.ufs.br/index.php/revtee/article/view/2952. Access on: Jan. 3, 2020. DOI: https://doi.org/10.20952/revtee.v0i0.2952.

FIGUEIREDO FILHO, D. B. et al. O que é, para que serve e como se faz uma meta-análise?. Revista Teoria \& Pesquisa, São Carlos, v. 23, n. 2, p. 205-228, 2014.

FOUCAULT, M. Microfísica do poder. 11. ed. Rio de Janeiro: Graal, 1993.

FRANÇA, F. G. R.; FERRARI, A. Mais do que professores/as, professores/as homossexuais na escola. Revista Tempos e Espaços em Educação, São Cristóvão, v. 9, n. 20, p. 41-52, 2016. Available at: https://seer.ufs.br/index.php/revtee/article/view/ 5894. Access on: Jan. 3, 2020. DOI: https://doi.org/10.20952/revtee.v9i20.5894.

FREIRE, P. Pedagogia do oprimido. 65. ed. Rio de Janeiro: Paz e Terra, 2018. 
GALAK, E. Pedagogías del cuerpo y del carácter en la "Revista de Educación" durante la gobernación de José Luís Cantilo (Buenos Aires, 1922-1926). Revista Tempos e Espaços em Educação, São Cristóvão, v. 10, n. 21, p. 149-162, 2017. Available at: https://seer.ufs.br/index.php/revtee/article/view/6339. Access on: Jan. 3, 2020. DOI: https://doi.org/10.20952/revtee.v10i21.6339.

GUZZI, J. 21 Gramos: el amor como epifenómeno de la tensión cuerpo-alma. Revista Tempos e Espaços em Educação, São Cristóvão, v. 12, n. 29, p. 213-226, 2019. Available at: https://seer.ufs.br/index.php/revtee/article/view/9514. Access on: Jan. 3, 2020. DOI: https://doi.org/10.20952/revtee.v12i29.9514.

HOOKS, b. Ensinando a transgredir: a educação como prática da liberdade. São Paulo: Martins Fontes, 2013.

IBGE - Instituto Brasileiro de Geografia e Estatística. Diferença do rendimento do trabalho de mulheres e homens nos grupos ocupacionais: Pesquisa Nacional por Amostra de Domicílios (PNAD) Contínua-2018. Brasília, DF: Agência de Notícias, 2019.

KAPLAN, C. V.; XAVIER, N. R. As infâncias na literatura latino-americana: quais os lugares da menina e da mulher negras?. Revista Tempos e Espaços em Educação, São Cristóvão, v. 11, n. $25, \quad$ p. 111-126, 2018. Available at: https://seer.ufs.br/index.php/ revtee/article/view/8797. Access on: Jan. 3, 2020. DOI: https://doi.org/10.20952/revtee. v11i25.8797.

MORAIS, A. B. A.; CARVALHO, M. E. P. Institucionalização dos estudos de gênero na universidade: uma análise a partir de narrativas de acadêmicas feministas. Revista Tempos e Espaços em Educação, São Cristóvão, v. 8, n. 17, p. 235-236, 2015. Available at: https://seer.ufs.br/index.php/revtee/article/view/4526. Access on: Jan. 3, 2020. DOI: https://doi.org/10.20952/revtee.v8i17.4526.

PINTO, É. J. S.; CARVALHO, M. E. P.; RABAY, G. As relações de gênero nas escolhas de cursos superiores. Revista Tempos e Espaços em Educação, São Cristóvão, v. 10, n. 22, p. 47-58, 2017. Available at: https://seer.ufs.br/index.php/revtee/article/ view/6173. Access on: Jan. 3, 2020. DOI: https://doi.org/10.20952/revtee.v10i22.6173.

PORTO, R.; GALVÃO, F. D. De Slutwalk à Marcha das Vadias: o imperativo dos feminismos em Natal (RN). Revista Tempos e Espaços em Educação, São Cristóvão, v. 9, n. 19, p. 147162, 2016. Available at: https://seer.ufs.br/index.php/revtee/ article/view/5602. Access on: Jan. 3, 2020. DOI: https://doi.org/10.20952/revtee.v9i19.5602.

PREINFALK-FERNÁNDEZ, M. L. La Educación sexual en el sistema educativo formal costarricense. Revista Tempos e Espaços em Educação, São Cristóvão, v. 9, n. 19, p. 103-112, 2016. Available at: https://seer.ufs.br/index.php/revtee/article/view/5599. Access on: Jan. 3, 2020. DOI: https://doi.org/10.20952/revtee.v9i19.5599. 
RIOS, P. P.; CARDOSO, H. M.; DIAS, A. F. Concepções de gênero e sexualidade d@s docentes do curso de licenciatura em Pedagogia: por um currículo Queer. Educação \& Formação, Fortaleza, v. 3, n. 8, p. 98-117, 2018. Available at: https://revistas.uece.br/ index.php/ redufor/article/view/272. Access on: Jan. 10, 2020. DOI: https://doi.org/ 10.25053/redufor.v3i8.272.

RODRIGUES, D. S.; FARO, L. C. A. Entre fronteiras semoventes: a constituição do feminino das filhas de lemanjá. Revista Tempos e Espaços em Educação, São Cristóvão, v. 12 , n. 29 , p. $61-80,2019$. Available at: https://seer.ufs.br/index.php/revtee/article/ view/11022. Access on: Jan. 3, 2020. DOI: https://doi.org/10.20952/revtee. v12i29.11022.

RODRIGUES, L. Transgredir para empoderar: o empoderamento das jovens mulheres pela educação. Revista Tempos e Espaços em Educação, São Cristóvão, v. 9, n. 18, p. 9198, 2016. Available at: https://seer.ufs.br/index.php/revtee/article/view/4967. Access on: Jan. 3, 2020. DOI: https://doi.org/10.20952/revtee.v9i18.4967.

RUDD, T.; GOODSON, I. F. Refraction as a tool for understanding action and educational orthodoxy and transgression. Revista Tempos e Espaços em Educação, São Cristóvão, v. 9, n. 18, p. 99-110, 2016. Available at: https://seer.ufs.br/index.php/revtee/article/ view/4968. Access on: Jan. 21, 2020. DOI: https://doi.org/10.20952/revtee.v9i18.4968.

SANTANA, A. M. Gênero, sexualidade e educação: perspectivas em debate. Revista Tempos e Espaços em Educação, São Cristóvão, v. 7, n. 12, p. 151-168, 2014. Available at: https://seer.ufs.br/index.php/revtee/article/view/2962. Access on: Jan. 3, 2020. DOI: https://doi.org/10.20952/revtee.v0i0.2962.

SANTANA, J. V. J. et al. Constituindo gêneros: sobre a produção de masculinidades e feminilidades na educação infantil. Revista Tempos e Espaços em Educação, São Cristóvão, v. 9, n. 20, p. 63-80, 2016. Available at: https://seer.ufs.br/index.php/ revtee/article/view/5896. Access on: Jan. 3, 2020. DOI: https://doi.org/10.20952/revtee. v9i20.5896.

SANTOS, A. C.; FELDENS, D. G. Vozes do triunfo: narrativas de si de professoras da educação básica. Revista Tempos e Espaços em Educação, São Cristóvão, v. 11, n. 1, p. 379-392, 2019. Available at: https://seer.ufs.br/index.php/revtee/article/view/9666. Access on: Jan. 3, 2020. DOI: https://doi.org/10.20952/revtee.v11i01.9666.

SANTOS, É. S.; LAGE, A. C. Gênero e diversidade sexual na educação básica: um olhar sobre o componente curricular Direitos Humanos e Cidadania da rede de ensino de Pernambuco. Revista Tempos e Espaços em Educação, São Cristóvão, v. 10, n. 22, p. 6982, 2017. Available at: https://seer.ufs.br/index.php/revtee/article/view/6042. Access on: Jan. 3, 2020. DOI: https://doi.org/10.20952/revtee.v10i22.6042. 
SANTOS, W. J.; SILVA, I. P. Revisão acerca dos temas alfabetização científica e ensino por investigação. Educa: Revista Multidisciplinar em Educação, Porto Velho, v. 5, n. 12, p. 138-150, 2018. Available at: http://www.periodicos.unir.br/index.php/educa/article/ view/3344. Access on: Jan. 22, 2020. DOI: http://dx.doi.org/10.26568/23592087.2018.3344.

SARAT, M.; CAMPOS, M. I. Gênero, sexualidade e infância: (con)formando meninas. Revista Tempos e Espaços em Educação, São Cristóvão, v. 7, n. 14, p. 45-56, 2014. Available at: https://seer.ufs.br/index.php/revtee/article/view/2951. Access on: Jan. 3, 2020. DOI: https://doi.org/10.20952/revtee.v0i0.2951.

SILVA JUNIOR, P. M.; IVENICKI, A. Entre sexualidades, masculinidades e raça: contribuições do multi/interculturalismo para a prática pedagógica. Revista Tempos e Espaços em Educação, São Cristóvão, v. 12, n. 29, p. 125-144, 2019. Available at: https://seer.ufs.br/index.php/revtee/article/view/9326. Access on: Jan. 3, 2020. DOI: https://doi.org/10.20952/revtee.v12i29.9326.

SILVA, I. P.; MERCADO, L. P. L. Revisão sistemática de literatura acerca da experimentação virtual no ensino de Física. Ensino \& Pesquisa, União da Vitória, v. 17, n. 1, p. 49-77, 2019. Available at: http://periodicos.unespar.edu.br/index.php/ensinoe pesquisa/article/view/2381. Access on: Jan. 22, 2020.

SILVA, M. A. C. Formação docente: do infinito ao particular! Narrativas sobre gênero, raça e religião. Revista Tempos e Espaços em Educação, São Cristóvão, v. 7, n. 12, p. 125136, 2014. Available at: https://seer.ufs.br/index.php/revtee/article/view/2960. Access on: Jan. 3, 2020. DOI: https://doi.org/10.20952/revtee.v0i0.2960.

SILVA, M. M. T.; TAVARES, C. Mulheres na luta: participação de mulheres nas ocupações de 2016 na Universidade Federal de Pernambuco. Revista Tempos e Espaços em Educação, São Cristóvão, v. 11, n. 27, p. 41-60, 2018. Available at: https://seer.ufs.br/index.php/revtee/article/view/7409. Access on: Jan. 3, 2020. DOI: https://doi.org/10.20952/revtee.v11i27.7409.

SILVA, T. T. Documentos de identidade: uma introdução às teorias do currículo. São Paulo: Autêntica, 2000.

SOUZA, L. P. Educação, gênero e raça: mapeando algumas desigualdades. Revista Tempos e Espaços em Educação, São Cristóvão, v. 7, n. 12, p. 113-124, 2014. Available at: https://seer.ufs.br/index.php/revtee/article/view/2959. Access on: Jan. 3, 2020. DOI: https://doi.org/10.20952/revtee.v0i0.2959.

THÜRLER, D.; DOS SANTOS, J. L. Um debate sobre a escola como tecnologia político- cultural. Revista Tempos e Espaços em Educação, São Cristóvão, v. 7, n. 14, p. 29-44, 2014. Available at: https://seer.ufs.br/index.php/revtee/article/view/2950. Access on: Jan. 3, 2020. DOI: https://doi.org/10.20952/revtee.v0i0.2950.

Educação \& Formação, Fortaleza, v. 5, n. 14, p. 150-175, maio/ago. 2020 
ULJENS, M. Non-Affirmative curriculum theory in a cosmopolitan era?. Revista Tempos e Espaços em Educação, São Cristóvão, v. 9, n. 18, p. 121-132, 2016. Available at: https://seer.ufs.br/index.php/revtee/article/view/4970. Access on: Jan. 21, 2020. DOI: https://doi.org/10.20952/revtee.v9i18.4970.

VIEIRA, C. M.; COELHO, M. A. Sexualidade e deficiência intelectual: concepções, vivências e o papel da educação. Revista Tempos e Espaços em Educação, São Cristóvão, v. 7, n. 14, p. 201-212, 2014. Available at: https://seer.ufs.br/index.php/revtee/article/view/3268. Access on: Jan. 3, 2020. DOI: https://doi.org/10.20952/revtee.v0i0.3268.

\section{Ivanderson Pereira da Silva (Maceió, Alagoas, Brasil) \\ Universidade Federal de Alagoas (UFAL), Departamento de Educação, Curso de Graduação em Pedagogia}

Degree in Physics (2008), specialist in Media in Education (2010), Master (2010) and Doctor in Education (2016), all training at UFAL. He is a professor at UFAL, Arapiraca campus, working on the undergraduate courses in Physics and Pedagogy. He is a permanent professor at the Post-Graduate Program in Teaching and Teacher Training at UFAL, Arapiraca campus, and at the Post-Graduate Program in Science and Mathematics Teaching (CEDU) at UFAL. She is the leader of the Research Group on Education, Media, Technologies and Society (GEEMTS) and currently holds a post-doctoral internship in the Graduate Program in Education at the Federal University of Sergipe.

Authorship contribution: Performed a systematic review of the material collected and contributed to the theoretical and methodological review.

Lattes: http://lattes.cnpq.br/3106780553307514.

E-mail: ivanderson@gmail.com.

\section{Alfrancio Ferreira Dias (Aracaju, Sergipe, Brasil) \\ Universidade Federal de Sergipe (UFS), Departamento de Educação, Curso de Graduação em Pedagogia}

Post-doctorate from the University of Warwick (2018), in the United Kingdom, and doctorate in Sociology from UFS. Adjunct professor III at the Department of Education at UFS. Coordinator of the Graduate Program in Education at UFS (Management 2016-2018 and Management 2018-2020). Vice-Leader of the Research Group: Education, Training, Work Process and Gender Relations, linked to the National Council for Scientific and Technological Development (CNPq). Researcher at the Center for Interdisciplinary Studies and Research on Women and Gender Social Relations (NEPIMG) at UFS. Editor of Tempos e Espaços em Educação magazine since 2014. Adjunct coordinator of the Forum of Editors of Education Periodicals (Fepae / Anped). Editorial Board - Portuguese from the Education Review Magazine of Arizona State University, United States. Visiting Research Fellow at the Center for the Study of Women and Gender at the University of Warwick, United Kingdom (2018). Develops research and extension on the following themes: Gender, Sexualities and Education; Teacher Education and Difference; Post-Critical Curriculum Studies; Queer Studies and Education; Queer Pedagogies. Authorship contribution: Performed a survey of the articles and contributed to the systematic review and the theoretical-methodological review.

Lattes: http://lattes.cnpq.br/1729817235900990.

E-mail: diasalfrancio@gmail.com. 


\section{Pedro Paulo Souza Rios (Salvador, Bahia, Brasil) \\ Universidade do Estado da Bahia (UNEB)}

$\mathrm{PhD}$ in Education from the Federal University of Sergipe (UFS), master in Education, Culture and Semiarid Territories from UNEB, specialist in Environmental Education from Facinter, in Contemporary Philosophy from Faculdade São Bento and in Youth and Adult Education from Universidade Cândido Mendes (UCAM ), graduated in Pedagogy from UNEB and in Philosophy from Faculdade Batista Brasileira (FBB) and Bachelor in Theology from Faculdade Católica do Ceará (FCC). Leader of the Study and Research Group on Education, Gender and Sexualities in the Sertão (Geneses-Sertão). Member of the Education, Society and Development Research Group. He is currently a substitute professor at UNEB, based on campus VII, in Senhor do Bonfim. Has experience in the areas of Education; Gender and Sexuality; Methodology of Scientific Work; Philosophy and Philosophy of Education; Anthropology of Education and Cultural; Youth and Adult Education; Contextualized Education and Supervised Curricular Internship; and Curriculum.

Authorship contribution: Performed a systematic review of the material collected and contributed to the theoretical and methodological review.

Lattes: http://lattes.cnpq.br/4706453501967580.

E-mail: peudesouza@yahoo.com.br.

Responsible publisher: Lia Machado Fiuza Fialho Ad hoc experts: Cristine Brandenburg e Karla Angélica Silva do Nascimento

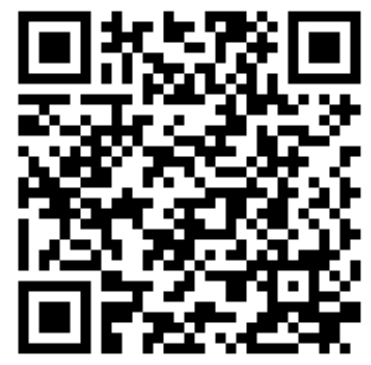

Received on January 23, 2020.

Accepted on January 31, 2020. 